Article

\title{
Casbane Diterpene as a Promising Natural Antimicrobial Agent against Biofilm-Associated Infections
}

\author{
Victor Alves Carneiro ${ }^{1, *}$, Hélcio Silva dos Santos ${ }^{2}$, Francisco Vassiliepe Sousa Arruda ${ }^{3}$, \\ Paulo Nogueira Bandeira ${ }^{2}$, Maria Rose Jane Ribeiro Albuquerque ${ }^{2}$, Maria Olívia Pereira ${ }^{4}$, \\ Mariana Henriques ${ }^{4}$, Benildo Sousa Cavada ${ }^{1}$ and Edson Holanda Teixeira ${ }^{1}$
}

1 Department of Biochemistry and Molecular Biology, Faculty of Medicine of Sobral, Federal University of Ceará, Fortaleza, CE, Brazil; E-Mails: bscavada@gmail.com (B.S.C.); edsonlec@gmail.com (E.H.T.)

2 Centre of the Exact Sciences and Technology, Acaraú Valley State University, 62040-370, Sobral, CE, Brazil; E-Mails: helciodossantos@gmail.com (H.S.S.); bandeirapn@yahoo.com.br (P.N.B.); rjane_7@hotmail.com (M.R.J.R.A.)

3 Northeast Biotechnology Network (RENORBIO), State University of Ceará, 60740-000, Fortaleza, CE, Brazil; E-Mail: vassiliepe@gmail.com (F.V.S.A.)

4 Centre for Biological Engineering, IBB-Institute for Biotechnology and Bioengineering, University of Minho, Campus de Gualtar, 4710-057 Braga, Portugal; E-Mails: mopereira@deb.uminho.pt (M.O.P.); mcrh@deb.uminho.pt (M.H.)

* Author to whom correspondence should be addressed; E-Mail: victorcarneiro@ufc.br; Tel.: +55-88-3611-8000; Fax: +55-88-3611-2202.

Received: 17 November 2010; in revised form: 29 November 2010 / Accepted: 20 December 2010 / Published: 30 December 2010

Abstract: Croton nepetaefolius is a native plant from northeastern Brazil that belongs to the Euphorbiaceae family. The biological action of this plant has been extensively explored, being the secondary metabolites responsible for its properties alkaloids, diterpenes, and triterpenes. This study aimed to evaluate the ability of casbane diterpene (CD), isolated from the ethanolic extract of $C$. nepetaefolius, to inhibit microbial growth and biofilm formation of several clinical relevant species (bacteria and yeasts). It was found that $\mathrm{CD}$ possessed biocidal and biostatic activity against the majority of the species screened, with minimal active concentrations ranging between 125 and $500 \mu \mathrm{g} / \mathrm{mL}$. In addition, it was observed that biofilm formation was inhibited even when the planktonic 
growth was not significantly affected. In conclusion, CD showed potential to be a natural tool for the treatment of diseases caused by different infectious microorganisms.

Keywords: casbane diterpene; biofilm-associated infections control; natural antimicrobials; bacteria and yeast

\section{Introduction}

In Nature, microorganisms often attach to surfaces and embed themselves in a matrix composed of extracellular polymeric substances, that they properly produce, forming a sessile population called biofilms [1,2]. Moreover, it is known that surface-associated microorganisms exhibited a distinct phenotype with respect to gene transcription, growth rate and enhanced resistance to antimicrobials $[3,4]$.

Biofilms are sources of diverse problems in various areas. In dairy industry, biofilms are often sources of biological contaminants and they also contribute to increased equipment corrosion rates [5]. In the public health sector, the colonization of medical surfaces, such as catheters and other indwelling devices, by biofilms, plays a decisive role in the problem of healthcare-associated infections [6]. Thus, over the years, many efforts have been put on the control of microbial adhesion and biofilm formation [7-11].

Currently, natural products are recognized as important antimicrobial agents with structural and mode of action diversity. Therefore, natural plant compounds have been used by many research groups with the intent of discovering new antimicrobial and anti-biofilm drugs or alternatives to antibiotic therapy [12-14]. Several thousand antimicrobial products have been discovered so far, showing high potential for therapeutical use [15].

The genus Croton of the plant family Euphorbiaceae is widespread in northeastern Brazil. The use of this genus in opular medicine includes treatments for cancer, constipation, diabetes, digestive problems, dysentery, external wounds, fever, hypercholesterolemia, hypertension, inflammation, intestinal worms, malaria, pain, ulcers, and weight-loss [16]. Previous phytochemical investigations have shown that plants of this genus produce alkaloids [17,18], flavonoids [19-21], triterpenoids and steroids [22,23], and a large number of diterpenoids [24-28]. Croton nepetaefolius is an aromatic plant native of the Northeast of Brazil which is extensively used in folk medicine as a sedative and antispasmodic agent [29]. Terpenoids are a class of secondary metabolites made of isoprene units. These molecules are reported as possessing antimicrobial properties [30,31], highlighting the antimicrobial potential of this important class of compounds.

In the present study, the biostatic and biocidal effects of casbane diterpene, a diterpenoid isolated from Croton nepetaefolius, was assessed against a wide range of microorganisms, both yeast and bacteria. Moreover, the effects of this compound on biofilm formation was also evaluated.

\section{Results and Discussion}

Bacteria and fungi are widely distributed in Nature, being some of them pathogenic and directly involved in several infectious diseases, such as cystic fibrosis, endocarditis, and periodontitis [32]. The 
casbane diterpene (CD) fraction extracted from Croton nepataefolius showed antimicrobial activity against some microorganisms tested (Figures 1 and 2). The presence of CD during bacteria growth clearly interfered with the Gram-positive bacterial planktonic and sessile development, inhibiting or reducing its growth. Concerning Staphylococcus aureus, $125 \mu \mathrm{g} / \mathrm{mL}$ of CD decreased its planktonic growth around $74 \%$ according to control absorbance, with MIC $250 \mu \mathrm{g} / \mathrm{mL}$ and MMC $500 \mu \mathrm{g} / \mathrm{mL}$ (Figure 1a). CD also interfered with the establishment of $S$. aureus biofilms, inhibiting their development at concentrations above $125 \mu \mathrm{g} / \mathrm{mL}$ (Figure 2a).

Figure 1. Antimicrobial activity of $C D$ on the planktonic growth of bacterial (a-j) and yeasts $(\mathrm{k}-\mathrm{m}) .{ }^{*} \mathrm{p}<0.01$ and $* * \mathrm{p}<0.001$ related to control.

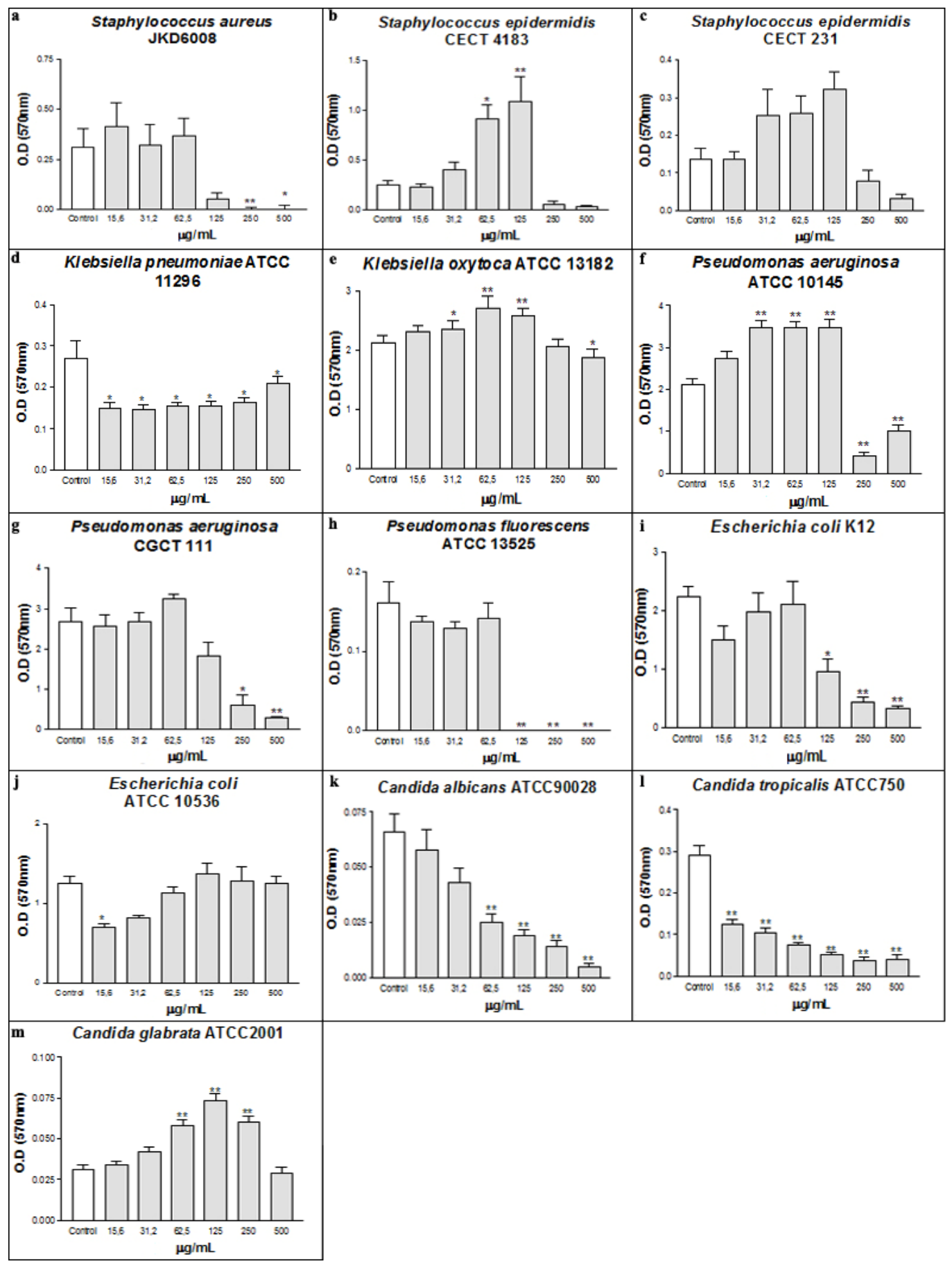


Figure 2. Antibiofilm effect of $C D$ on bacterial $(a-j)$ and yeasts $(k-m)$. ${ }^{*} p<0.01$ and $* * \mathrm{p}<0.001$ related to control.
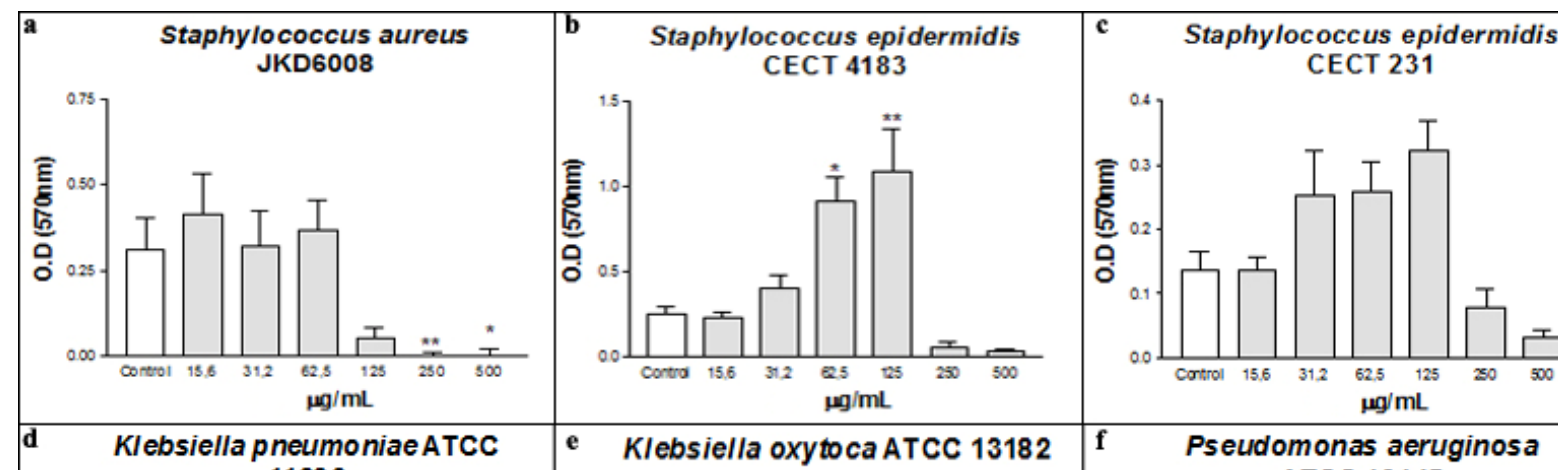
11296
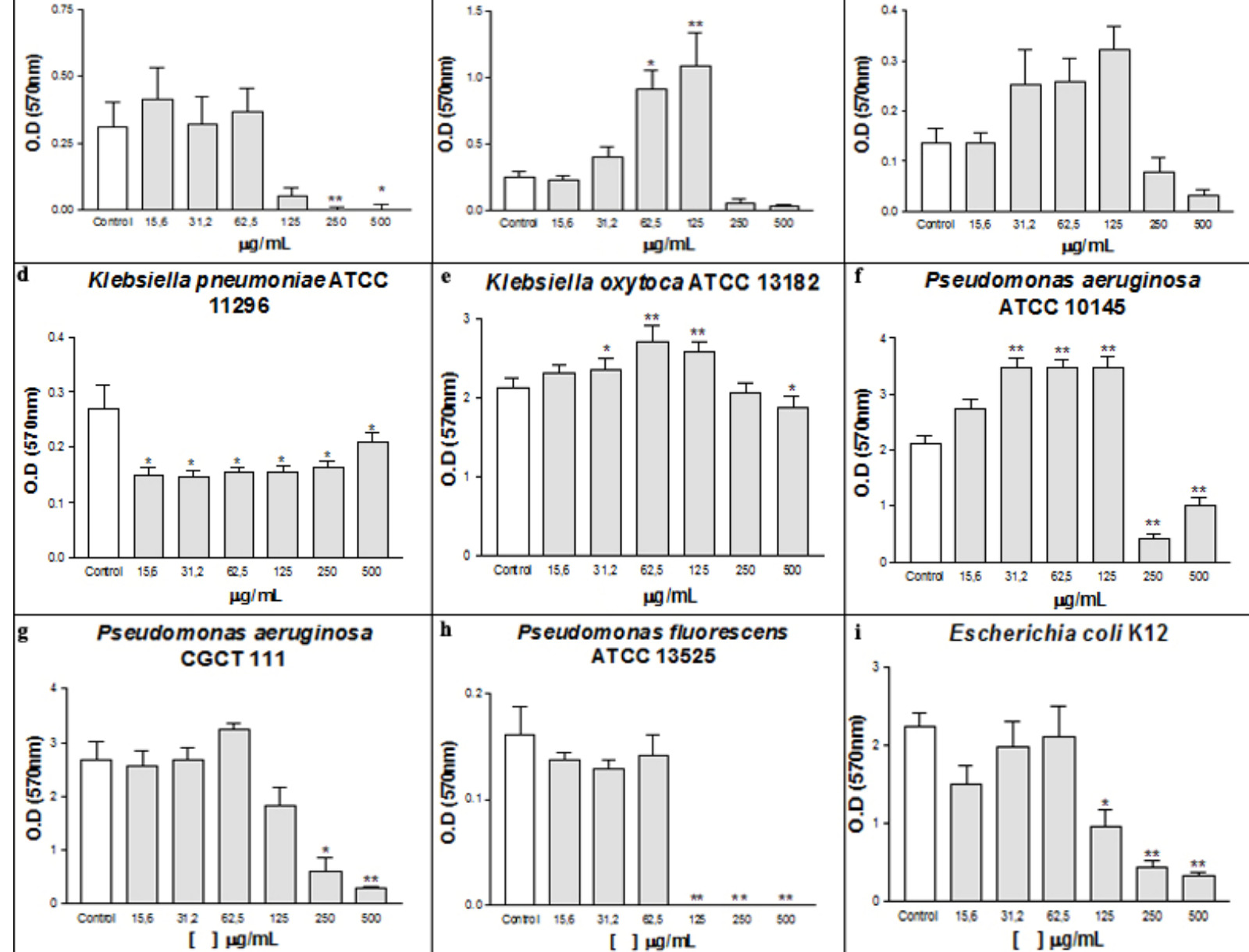

ATCC 13525

Escherichia coli $\mathrm{K} 12$
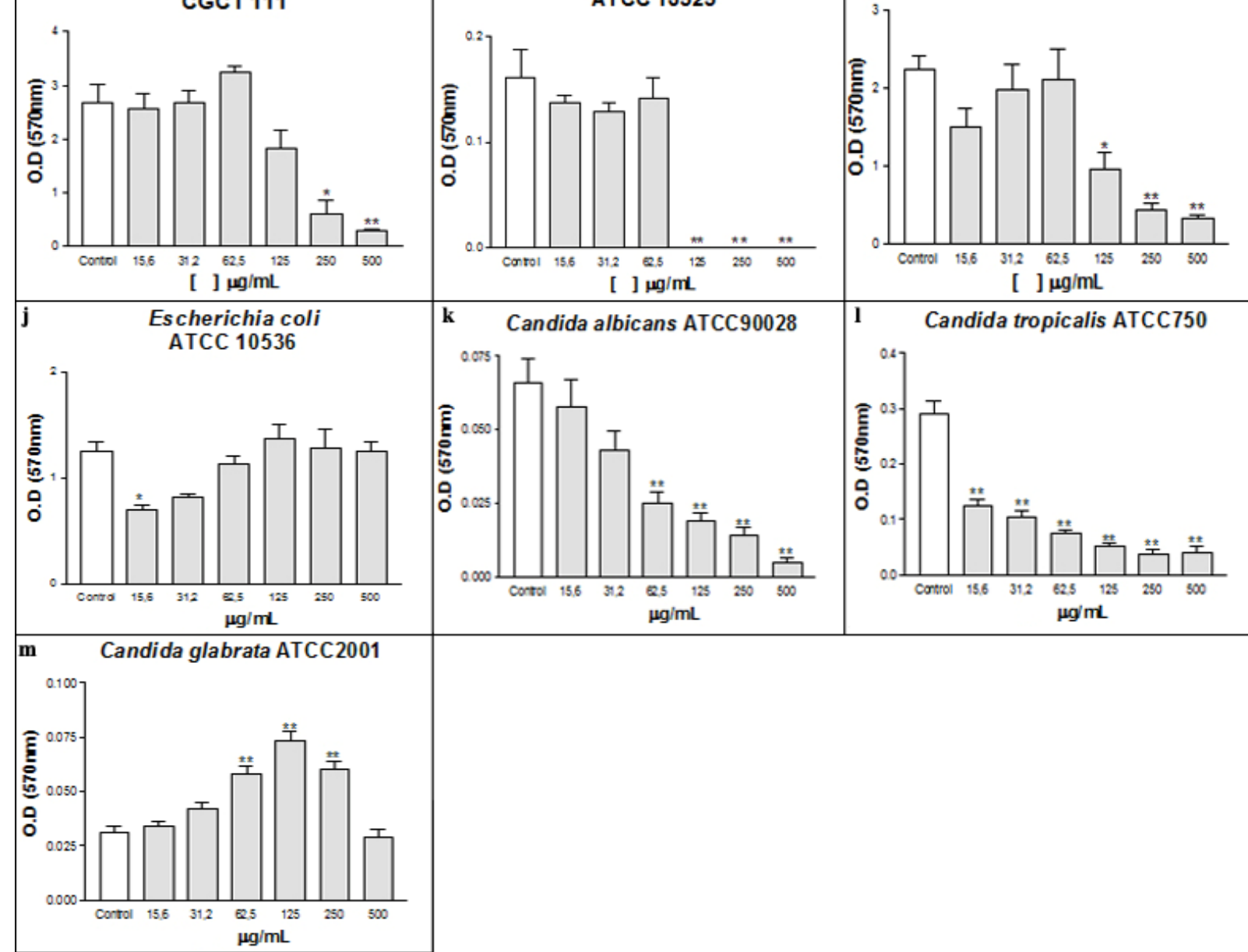

Regarding Staphylococcus epidermidis strains, CD also showed ability to reduce their planktonic growth at concentrations above $62.4 \mu \mathrm{g} / \mathrm{mL}$, with MIC of $500 \mu \mathrm{g} / \mathrm{mL}$ without bactericidal activity 
(Figures $1 \mathrm{~b}$ and 1c). Biofilm formation by S. epidermidis CECT 4183 is clearly disturbed by CD at doses above $250 \mu \mathrm{g} / \mathrm{mL}$ (Figure $2 \mathrm{~b}$ ). No significant effect was found on $S$. epidermidis CECT 231 (Figure 2c). So, based on the results it can be concluded that CD exhibited excellent antibacterial profile on the Gram-positive bacteria tested.

As already reported [33,34], the cell membrane has a great importance in many cellular processes, including permeability, cell growth and division. Considering the chemical characteristics of the molecule tested, hidrophobicity and polarity, a non-specific interaction with membrane phospholipids, destabilizing the non-covalent interactions between the fatty acids of the lipid bilayer, and thus interfering with the cellular development of the Gram-positive bacteria can be suggested. Molecules with lipophilic characteristics such as anthraquinones are known antimicrobial substances, which exhibit such an effect of interaction with cell membrane phospholipids [35,36]. The effect on biofilm formation by the Gram-positive staphylococcal strains seems to be directly related to the growth inhibition, showing non-specific action related to the antibiofilm activity.

The effect of $\mathrm{CD}$ was different on Gram-negative strains, being able to interfere only in the development of the biofilm, without affecting the planktonic growth, with the exception of $P$. fluorescens ATCC 13525 (Figure 1d). The presence of the outer membrane in Gram-negative bacteria constitutes a barrier for permeability of hydrophobic molecules [37]. Thus, the interaction of CD with the cellular membrane was limited, and the antibacterial effect was inhibited. These microorganisms, when associated in biofilms, are structurally and physiologically different from planktonic bacteria, for example, in their resistance to antibiotics [38].

In recent years, researchers have explored the activity of natural products possessing the ability to interfere with the development of biofilms [39,40]. At the lowest concentration $(15.6 \mu \mathrm{g} / \mathrm{mL})$ biofilm formation by Klebsiella pneumoniae ATCC 11296 was decreased by about 45\% (Figure 2d). Concerning Pseudomonas aeruginosa ATCC 10145, CD at doses ranging between 31.2 and $125 \mu \mathrm{g} / \mathrm{mL}$ induced biofilm mass production, while concentrations above $250 \mu \mathrm{g} / \mathrm{mL}$ strongly inhibited biofilm development by around $80 \%$ (Figure 2f). A similar trend occurred for Pseudomonas aeruginosa CGCT 111 and Escherichia coli K12 strains, since the highest concentration of CD led to an inhibition of $86 \%$ (Figure $2 \mathrm{~g}$ and Figure $2 \mathrm{i}$ ). The increase of biomass observed in the $P$. aeruginosa ATCC10145 can be explained by stress induced by the presence of the tested substance that maybe leads to an extra production of exopolysaccharides (EPS) by the bacterial cell. A similar effect was observed at sub-inhibitory concentrations of cefotaxime, which significantly induced the production of biofilm mass as well as EPS of three Salmonella enterica isolates [41]. Against Pseudomonas fluorescens, CD showed MIC and MMC of $125 \mu \mathrm{g} / \mathrm{mL}$ and $250 \mu \mathrm{g} / \mathrm{mL}$, respectively (Figure 1d). Moreover, there was no biofilm formation by this Gram-negative strain at concentrations above $125 \mu \mathrm{g} / \mathrm{mL}$ (Figure 2h). The lipopolysaccharide (LPS) present in the cell surface, placed on outer leaflet of the outer membrane of all Gram-negative bacteria, forms the first point of contact between the bacterial cell and any surface that it colonizes or binding to therapeutic agents [42]. Studies indicate that biofilm formation of $P$. aeruginosa is directly related to the type of LPS produced by the cell [43]. Thus, the effect of $C D$ on inhibition of biofilm formation may be related to an interaction between CD and LPS, which might affect the adherence properties influencing thus biofilm formation by these strains. 
As occurred in Gram-positive bacteria, CD was effective on planktonic growth of the yeasts tested. On C. albicans and C. tropicalis strains $\mathrm{CD}$, at concentrations of $500 \mu \mathrm{g} / \mathrm{mL}$, reduced viability of planktonic growth in 59\% and 29\%, respectively (Figure $1 \mathrm{k}$ and Figure 11). However, on C. glabrata, the $\mathrm{CD}$ was effective in a lower concentration $(15.6 \mu \mathrm{g} / \mathrm{mL})$ and was able to decrease by $72 \%$ the yeast viability when its concentration was $500 \mu \mathrm{g} / \mathrm{mL}$ (Figure $1 \mathrm{~m}$ ). In the biofilm formation experiments using yeasts, $\mathrm{CD}$ proved to be effective on $C$. albicans and $C$. tropicalis strains, showing a doseresponse relationship (Figure $2 \mathrm{k}$ and Figure 21). Regarding C. tropicalis, $\mathrm{CD}$ at a concentration of $15.6 \mu \mathrm{g} / \mathrm{mL}$ decreased more than $50 \%$ the yeast ability to form biofilm (Figure 21 ). When used against C. albicans, $62.5 \mu \mathrm{g} / \mathrm{mL}$ of the CD was necessary to achieve the same reduction (Figure $2 \mathrm{k}$ ). On the other hand, $C D$ increased the biomass production of $C$. glabrata (Figure $2 \mathrm{~m}$ ). The differences in $\mathrm{CD}$ activity can be explained by differences in phosphoglycerides components and fatty acyl chains of Candida species [44].

\section{Experimental}

\subsection{Plant material}

Stalks from C. nepetaefolius were collected in Caucaia - Ceará (Brazil) in May 2004. The material was identified by Dr. Edson Paula Nunes at the Herbário Prisco Bezerra (EAC), Departamento de Biologia, Universidade Federal do Ceará, Fortaleza, CE, Brazil, where the voucher specimens (No. 33.582) were deposited.

\subsection{Extraction and isolation of casbane diterpene}

The bark $(5.0 \mathrm{~kg})$ of $C$. nepetaefolius was powdered and extracted with ethanol $(\mathrm{EtOH}),(10 \mathrm{~L} \times 3$, for three days) at room temperature. The solvent was removed under reduced pressure to give an EtOH extract $(58.2 \mathrm{~g})$ that was fractionated coarsely on a silica gel column by elution with hexane (fractions 1-15), hexane/ethyl acetate (EtOAc) (1:1 fractions 16-25), EtOAc (fractions 26-40), and EtOH (fractions 41-48), affording a total of 48 fractions of $100 \mathrm{~mL}$ each. The hexane fractions $(22.5 \mathrm{~g})$ were pooled and fractionated on a silica gel column using hexane (fractions 1'-10'), hexane/EtOAc (1:1 F' 11-16), EtOAc (F' 17-21) and EtOH (F' 22-25), providing 25 fractions of $100 \mathrm{~mL}$ each. Fractions $11^{\prime}-16$ ' (14.0), obtained with hexane/EtOAc (1:1), was fractionated coarsely on a silica gel column by elution with hexane (F" 1), hexane/EtOAc (9:1 F" 2-5; 8:2 F" 6-15; 7:3 F" 16-32), EtOAc (F" 33), providing 33 fractions of $100 \mathrm{~mL}$ each. Fractions 10"-13", obtained with hexane/EtOAc (8:2), yielded diterpene named 1,4-dihydroxy-2E,6E,12E-trien-5-one-casbane (3.0 g, 0.06\%; Figure 3). 
Figure 3. Structure of casbane diterpene extracted from the stalks of Croton nepetaefolius.

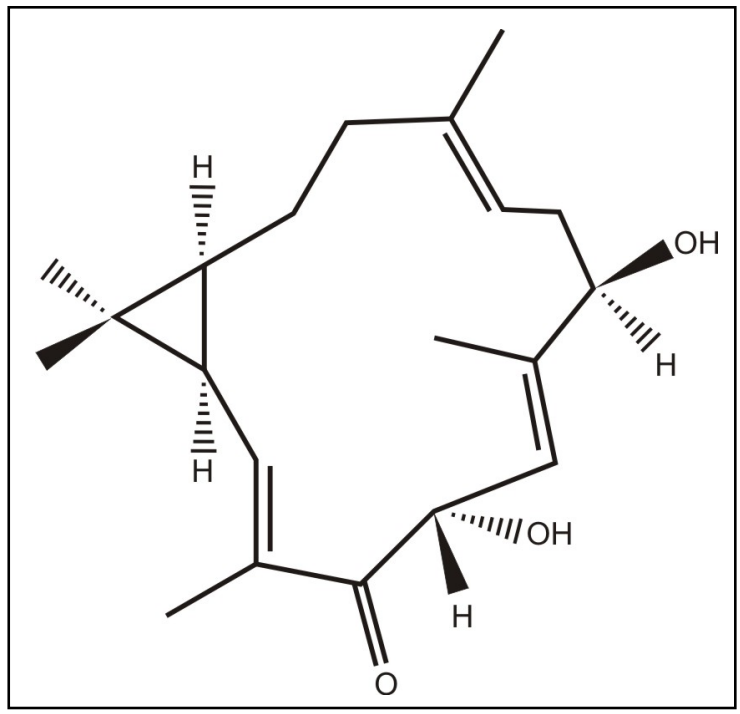

\subsection{Preparation of the CD stock solution}

The CD was solubilized in dimethyl sulfoxide (DMSO), and then diluted in culture medium $(1 \mathrm{mg} / \mathrm{mL})$, with a maximum percentage of $4 \%$ of DMSO. Controls were performed to confirm that this dose of DMSO did not interfere with microbial growth.

\subsection{Microorganisms}

In the present study, the microorganisms used in the experiments were: Gram negative bacteria (Pseudomonas fluorescens ATCC13525, Pseudomonas aeruginosa ATCC10145, P. aeruginosa CGCT111, Klebsiella oxytoca ATCC13182, Klebsiella pneumoniae ATCC11296, Escherichia coli K12 MG 1655, and Escherichia coli CECT434), Gram-positive bacteria (Staphylococcus epidermidis CECT231, S. epidermidis CECT4183, and S. aureus ATCC), and yeasts (Candida albicans ATCC90028, C. tropicalis ATCC750 and C. glabratta ATCC2001).

\subsection{Culture conditions}

For each microorganism, a culture stock was prepared on Tryptic Soy broth (TSB) plus 20\% glycerol and preserved at $-80{ }^{\circ} \mathrm{C}$. Then, the microorganisms were transferred into Petri dishes containing TSA and incubated at $37^{\circ} \mathrm{C}$, for $24 \mathrm{~h}$. After growth on the solid medium, an isolated colony was removed and inoculated into $10 \mathrm{~mL}$ of TSB and incubated for $18 \mathrm{~h}$ at $37{ }^{\circ} \mathrm{C}$ under constant agitation of $120 \mathrm{rpm}$. Prior to use, the cell concentration of each inoculum was adjusted to $1 \times 10^{6}$ cells $/ \mathrm{mL}$ through the use of spectrophotometer and calibration curves, previously determined for each bacterium. The yeasts were cultured for $24 \mathrm{~h}$ in RPMI 1640 buffered with MOPS at $\mathrm{pH} 7.0$ in constant agitation of $120 \mathrm{rpm}$. Then, the concentration of each yeast inoculum was adjusted to $1 \times 10^{6}$ cells $/ \mathrm{mL}$ using a Neubauer chamber. 


\subsection{Antimicrobial assays}

The antimicrobial effects of CD were determined by the broth microdilution method in 96 -well polystyrene plates, according to the guideline Methods for Dilution Antimicrobial Susceptibility Tests for Bacteria That Grow Aerobically; Approved Standard - Sixth Edition (NCCLS document M7-A6). CD was diluted in culture medium, RPMI 1640 for yeast or TSB for bacteria, to achieve 15.6 to $500 \mu \mathrm{g} / \mathrm{mL}$ were incubated aerobically with $1 \times 10^{6}$ cells $/ \mathrm{mL}$, initial concentration of cells, on a horizontal shaker $(120 \mathrm{rpm} / \mathrm{min})$, at $37{ }^{\circ} \mathrm{C}$, during $24 \mathrm{~h}$. The optical density at $640 \mathrm{~nm}\left(\mathrm{OD}_{640}\right)$ of each well content was recorded using an automated Elisa Reader (Synergy TM HT Multi-Detection Microtiter Reader), as a measure of microbial growth.

The minimum inhibitory concentration (MIC) for each microorganism was determined as the lowest concentration of $\mathrm{CD}$ at which there is complete inhibition of visible growth of the organism. To determine the minimum microbicidal concentration (MMC), $10 \mu \mathrm{L}$ of the bacteria/yeast planktonic cultures, where no visible microbial growth was observed, were inoculated in petri dishes with TSA medium and incubated at $37^{\circ} \mathrm{C}$ for $24 \mathrm{~h}$. MMC was considered as being the lowest concentration able to completely inhibit microbial growth on the plates.

\subsection{Antibiofilm activity}

The methodology used to grow biofilms was based on the microtiter plate test developed by Stepanovic et al. [45], with some modifications. Sterile 96-well polypropylene tissue culture plates (Orange Scientific, Braine-l'Alleud, Belgium) (with flat-bottom) were prepared using a procedure similar to the one used in the antimicrobial activity tests with same initial concentration of cells. All the plates were incubated aerobically on a horizontal shaker $(120 \mathrm{rpm} / \mathrm{min})$, at $37{ }^{\circ} \mathrm{C}$ during $24 \mathrm{~h}$ for biofilm development. After biofilm growth in the presence or absence of same CD concentrations, the content of each well was removed and the biofilms were washed twice with $200 \mu \mathrm{L} /$ well of sterilized water, to remove cells weakly adhered, being reserved for posterior analysis.

Biomass quantification: The attached biofilm mass was quantified using crystal violet staining [46]. Briefly, the plates containing the biofilms were let to air dry for $30 \mathrm{~min}$, and $200 \mu \mathrm{L}$ of absolute methilic alcohol were transferred to each well, in order to fix the adhered cells, and allowed to contact during for $15 \mathrm{~min}$. After $15 \mathrm{~min}$, the methanol was removed and $200 \mu \mathrm{L}$ of crystal violet $1 \%$ (Gram colour-staining set for microscopy; Merck) per well were added for $5 \mathrm{~min}$. After the staining step, the washing process, with sterile water, was repeated and the plates were placed at room temperature for 1 hour. To re-solubilize the dye bounded to biofilms, $200 \mu \mathrm{L}$ of $33 \%$ (v/v) glacial acetic acid (Merck) was added to each well and place in agitation for $15 \mathrm{~min}$. The CV solutions obtained were transferred to a new sterile 96-well plate and the optical density of the content of each well was measured using a microtiter plate spectrophotometer (Sunrise - Tecam) at $570 \mathrm{~nm}$.

\subsection{Statistical analysis}

Statistical analyses were performed by GraphPad Prism ${ }^{\circledR}$ version 3.00 from Microsoft Windows ${ }^{\circledR}$. The method used was one-way ANOVA with Bonferroni post hoc test. The data were obtained in 
triplicates from at least three separate experiments. The graphs were presented as mean \pm standard deviation. The data were considered significant when $\mathrm{p}<0.01$ or $\mathrm{p}<0.001$.

\section{Conclusions}

Biofilm eradication is a crucial step for the treatment of various diseases. In the present work, a novel and natural agent with a promising antimicrobial activity was described. Casbane diterpene (CD) showed antimicrobial effect on planktonic forms and biofilm from some bacteria and yeasts. The results showed that $\mathrm{CD}$ can be considered as a promising molecule with potential for the pharmacological treatment of biofilm-associated infections. Additional toxicological studies need to be performed to validate its applicability.

\section{Acknowledgements}

This study was supported by FUNCAP and CNPq (Brazil) and by FCT (Portugal) through the project PTDC/SAU-ESA/64609/2006.

\section{References and Notes}

1. Rehm, B.H.A. Bacterial polymers: biosynthesis, modifications and applications. Appl. Ind. Microbiol. 2010, 8, 578-592.

2. Simões, M.; Simões, L.C.; Vieira, M.J. A review of current and emergent biofilm control strategies. Food Sci. Technol. 2010, 43, 573-583.

3. Johnson, J.G.; Clegg, S. Role of MrkJ, a phosphodiesterase, in type 3 fimbrial expression and biofilm formation in Klebsiella pneumoniae. J. Bacteriol. 2010, 192, 3944-3950.

4. Kajiyama, S.; Tsurumoto, T.; Osaki, M.; Yanagihara, K.; Shindo, H. Quantitative analysis of Staphylococcus epidermidis biofilm on the surface of biomaterial. J. Orthopaed. Sci. 2009, 14, 769-767.

5. Bremer, P.J.; Fillery, S.; McQuillan, A.J. Laboratory scale Clean-In-Place (CIP) studies on the effectiveness of different caustic and acid wash steps on the removal of dairy biofilms. Int. J. Food Microbiol. 2006, 106, 254-262.

6. Hammond, A.M.S.; Dertien, J.M.S.; Colmer-Hamood, J.A.; Griswold, J.A.M.D.; Hamood, A.N. Serum Inhibits $P$. aeruginosa Biofilm Formation on Plastic Surfaces and Intravenous. J. Surg. Res. 2010, 159, 735-746.

7. Toney, J.H.; Koh, M.L. Inhibition of Xylella fastidiosa Biofilm Formation via Metal Chelators. J. Assoc. Lab. Automat. 2006, 11, 30-32.

8. Cheng, G.; Zhang, Z.; Chen, S.; Bryers, J.D.; Jiang, S. Inhibition of bacterial adhesion and biofilm formation on zwitterionic surfaces. Biomaterials 2007, 28, 4192-4199.

9. Cateau, E.; Berjeaud, J.M.; Rodiera, M.H.; Christine, I. Fungal biofilm inhibition by a component naturally produced by Candida albicans yeasts growing as a biofilm. Int. J. Antimicrob. Agents 2008, 31,166-170. 
10. Wanga, X.; Yao, X.; Zhua, Z.; Tanga, T.; Daia, K.; Sadovskayac, I.; Flahautc, S.; Jabbouri, S. Effect of berberine on Staphylococcus epidermidis biofilm formation. Int. J. Antimicrob. Agents 2009, 34, 60-66.

11. Okuda, K.; Hanada, N.; Usui Y.; Takeuchi, H.; Koba, H.; Nakao, R.; Watanabe, H.; Senpuku, H. Inhibition of Streptococcus mutans adherence and formation using analogues of the SspB peptide. Arch. Oral Biol. 2010, 55, 754-762.

12. Ndi, C.P.; Semple, S.J.; Griesser, H.J.; Pyke, S.M.; Barton, M.D. Antimicrobial Compounds from the Australian Desert Plant Eremophila neglecta. J. Nat. Prod. 2007, 70, 1439-1443.

13. Horiuchi, K.; Shiota, S.; Hatano, T.; Yoshida, T.; Kuroda, T.; Tsuchiya, T. Antimicrobial activity of oleanolic acid from Salvia officinalis and related compounds on vancomycin-resistant enterococci (VRE). Biol. Pharm. Bull. 2007, 30, 1147-1149.

14. Viano, Y.; Bonhomme, D.; Camps, M.; Briand, J.F.; Ortalo-Magné, A.; Blache, Y.; Piovetti, L.; Culioli, G. Diterpenoids from the Mediterranean brown alga Dictyota sp. evaluated as antifouling substances against a marine bacterial biofilm. J. Nat. Prod. 2009, 72,1299-1304.

15. Behal, V. Nontraditional microbial bioactive metabolites. Folia Microbiol. 2001, 46, 363-370.

16. Salatino, A.; Salatino, M.L.F.; Negri, G. Traditional uses, chemistry and pharmacology of Croton species (Euphorbiaceae). J. Braz. Chem. Soc. 2007, 18, 11-33.

17. Murillo, R.M.; Jakupovic, J.; Rivera, J.; Castro, V.H. Diterpenes and other constituents from Croton draco (Euphorbiaceae). Rev. Biol. Trop. 2001, 49, 259-264.

18. Araujo-Junior, V.T.; da Silva, M.S.; da Cunha, E.V.L.; Agra, M.D.; da Silva, R.N.; Barbosa, J.M.; Braz-Filho, R. Alkaloids and Diterpenes From Croton moritibensis. Pharm. Biol. 2004, 42, 62-67.

19. Peres, M.T.L.P.; Monache, F.D.; Cruz, A.B.; Pizzolatti, M.G.; Yunes, R.A.J. Chemical composition and antimicrobial activity of Croton urucurana Baillon (Euphorbiaceae). J. Ethnopharmacol. 1997, 56, 223-226.

20. Maciel, M.A.M.; Pinto, A.C.; Arruda, A.C.; Pamplona, S.G.S.R.; Vanderlinde, F.A.; Lapa, A.J.; Echevarria, A.; Grynberg, N.F.; Côlus, I.M.S.; Farias, R.A.F.; Costa, A.M.L.; Rao, V.S.N. Ethnopharmacology, phytochemistry and pharmacology: a successful combination in the study of Croton cajucara. J. Ethnopharmacol. 2000, 70, 41-55.

21. Graikou, K.; Aligiannis, N.; Skaltsounis, A.L.; Chinou, I.; Michel, S.; Tillequin, F.; Litaudon, M. New diterpenes from Croton insularis. J. Nat. Prod. 2004, 67, 685-688.

22. Peres, M.T.L.P.; Monache, F.D.; Pizzolatti, M.G.; Santos, A.R.S.; Beirith, A.; Calixto, J.B.; Yunes, R.A. Analgesic compounds of Croton urucurana Baillon. Pharmaco-chemical criteria used in their isolation. Phytother. Res. 1998, 12, 209-211.

23. Guadarrama, A.B.A.; Rios, M.Y. Three new sesquiterpenes from Croton arboreus. J. Nat. Prod. 2004, 67, 914-917.

24. McChesney, J.D.; Silveira, E.R. Ent-clerodanes of Croton sonderianus. Fitoterapia 1990, 61, 172-175.

25. El Mekkawy, S.; Meselhy, M.R.; Nakamura, N.; Hattori, M.; Kawahata, T.; Otake, T. Anti-HIV-1 phorbol esters from the seeds of Croton tiglium. Phytochemistry 2000, 53, 457-464.

26. Barbosa, P.R.; Fascio, M.; Martins, D.; Guedes, M.L.S.; Roque, N.F. Triterpenes of Croton betulaster (Euphorbiaceae). Biochem. Syst. Ecol. 2003, 31, 307-308. 
27. Giang, P.M.; Son, P.T.; Lee, J.H.; Lee, J.J.; Otsuka, H. Four ent-kaurane diterpenoids from Croton tonkinensis Gagnep. Chem. Pharm. Bull. 2004, 52, 879-882.

28. Santos, H.S.; Barros, F.W.A.; Albuquerque, M.R.J.R.; Bandeira, P.N.; Pessoa, C.; Braz-Filho, R.; Monte, F.J.Q.; Leal-Cardoso, J.H.; Lemos, T.L.G. Cytotoxic Diterpenoids from Croton argyrophylloides. J. Nat. Prod. 2009, 72, 1884-1887.

29. Santos, H.S.; Mesquita, F.M.R.; Lemos, T.L.G.; Monte, F.J.Q.; Braz-Filho, R. Diterpenos casbanos e acetofenonas de Croton nepetaefolius (Euphorbiaceae).Quím. Nova 2008, 31, 601-604.

30. Sarikahya, N.B.; Kirmizigül, S. Antimicrobial triterpenoid glycosides from Cephalaria scoparia. J. Nat. Prod. 2010, 73, 825-830.

31. Souza, A.B.; Martins, C.H.; Souza, M.G.; Furtado, N.A.; Heleno, V.C.; de Sousa, J.P.; Rocha, E.M.; Bastos, J.K.; Cunha, W.R.; Veneziani, R.C.; Ambrósio, S.R. Antimicrobial activity of terpenoids from Copaifera langsdorffii Desf. against cariogenic bacteria. Phytother. Res. 2010, DOI: $10.1002 /$ ptr.3244.

32. Donlan, R.M. Biofilms: microbial life on surfaces. Emerg. Infect. Dis. 2002, 8, 881-890.

33. Roy, H. Tuning the properties of the bacterial membrane with aminoacylated phosphatidylglycerol. IUBMB Life 2009, 61, 940-953.

34. Priyadarshini, R.; de Pedro, M.A.; Young, K.D. Role of peptidoglycan amidases in the development and morphology of the division septum in Escherichia coli. J. Bacteriol. 2007, 189, 5334-5347.

35. Coenye, T.; Honraet, K.; Rigole, P.; Nadal, J.P.; Nelis, H.J. In vitro inhibition of Streptococcus mutans biofilm formation on hydroxyapatite by subinhibitory concentrations of anthraquinones. Antimicrob. Agents Chemother. 2007, 51, 1541-1544.

36. Xiang, W.; Song, Q.S.; Zhang, H.J.; Guo, S.P.; Antimicrobial anthraquinones from Morinda angustifolia. Fitoterapia 2008, 79, 501-504.

37. Silipo, A.; Molinaro, A. The diversity of the core oligosaccharide in lipopolysaccharides. Subcell. Biochem. 2010, 53, 69-99.

38. Xu, K.D.; McFeters G.A.; Stewart, P.S. Biofilm resistance to antimicrobial agents. Microbiology 2000, 3,547-549.

39. Taweechaisupapong, S.; Singhara, S.; Lertsatitthanakorn, P.; Khunkitti, W. Antimicrobial effects of Boesenbergia pandurata and Piper sarmentosum leaf extracts on planktonic cells and biofilm of oral pathogens. Pakistan J. Pharm. Sci. 2010, 23, 224-231.

40. Kuzma, L.; Rózalski, M.; Walencka, E. Rózalska, B.; Wysokinska, H. Antimicrobial activity of diterpenoids from hairy roots of Salvia sclarea L.: Salvipisione as a potential anti-biofilm agent active against antibiotic resisrant Staphylococci. Phytomedicine 2007, 14, 31-35.

41. Majtán, J.; Majtánová, L.; Xu, M.; Majtán, V. In vitro effect of subinhibitory concentrations of antibiotics on biofilm formation by clinical strains of Salmonella enterica serovar Typhimurium isolated in Slovakia. J. Appl. Microbiol. 2007, 104, 1294-1301.

42. Lau, P.C.; Lindhout, T.; Beveridge, T.J.; Dutcher, J.R.; Lam, J.S. Differential lipopolysaccharide core capping leads to quantitative and correlated modifications of mechanical and structural properties in Pseudomonas aeruginosa biofilms. J. Bacteriol. 2009, 191, 6618-6631.

43. Rocchetta, H.L.; Burrows, L.L.; Lam, J.S. Genetics of O-antigen biosynthesis in Pseudomonas aeruginosa. Microbiol. Mol. Biol. Rev. 1999, 63, 523-553. 
44. Singh, A.; Prasad, T.; Kapoor, K.; Mandal, A.; Roth, M.; Welti, R.; Prasad, R. Phospholipidome of Candida: Each Species of Candida Has Distinctive Phospholipid Molecular Species. OMICS A J. Integr. Biol. 2010, 14, 1-14.

45. Stepanovic, S.; Vukovic, D.; Dakic, I.; Savic, B.; Svabic-Vlahovic, M. A modified microtiterplate test for quantification of staphylococcal biofilm formation. J. Microbiol. Methods 2000, 40, 175-179.

46. Burton, E.; Yakandawala, N.; LoVetri, K.; Madhyastha, M.S. A microplate spectrofluorometric assay for bacterial biofilms. J. Ind. Microbiol. Biotechnol. 2007, 34, 1-4.

Sample Availability: Contact the authors.

(C) 2010 by the authors; licensee MDPI, Basel, Switzerland. This article is an open access article distributed under the terms and conditions of the Creative Commons Attribution license (http://creativecommons.org/licenses/by/3.0/) 